\title{
LOCAL GOVERNMENT AND POLICY NETWORKS IN THE UK: AN ANALYTICAL STUDY
}

\author{
M. Khalifa \\ Applied Science University \\ 315 Shabab Road, Manama, Bahrain \\ Suez Canal University \\ 4.5 Km the Ring Road, Ismailia, Egypt, 41522
}

\begin{abstract}
In the United Kingdom, local government includes authorities and subordinate agencies that are established according to the law, under the direction of a locally elected council to provide services for their local neighborhoods and represent their concerns and interests. The United Kingdom does not have a federal government, like the United States; there is no division of powers between the central government and local units. The central government has all governmental powers and is dominantly responsible for public policy making. The research will clarify the function of local government and identify the relationship between the central government and local authorities. It will also analyze modern models of policy networks in the UK and demonstrate their difference from the federal system.
\end{abstract}

Key words: local government, policy networks, local authorities, public policy

\section{THE STRUCTURE OF LOCAL GOVERNMENT IN ENGLAND}

The United Kingdom consists of four countries: England, Wales, Scotland and Northern Ireland. The constituent units of Great Britain are England, Scotland and Wales; Britain consists of England and Wales [17. P. 4].

In England, the highest tier of sub-national division established by the central government is regions. Between 1994 and 2011, the model of local government in England was very complex, with no separate governing body for the whole country other than the Government of the United Kingdom.

There are nine regions which have an administrative role in the implementation of UK Government policy. There are also areas governed (mostly indirectly) by elected bodies, such as Greater London which has an elected Assembly and Mayor, but the other regions play a relatively minor role in comparison, with unelected regional assemblies and regional development agencies.

England has five types of local authorities, each one of them either single-tier or two-tier.

\section{SINGLE-TIER AUTHORITIES}

These authorities are responsible for providing all local government services; in other words, they are all-purpose councils. It applies to three types of authorities, including:

\section{A) Metropolitan Authorities}

The metropolitan counties are a type of county-level administrative division of England. There are six metropolitan counties - Greater Manchester, Merseyside, 
South Yorkshire, Tyne and Wear, West Midland and West Yorkshire. Each one covers a large urban area, typically with populations of 1.2 to 2.8 million; the six metropolitan counties are divided into 36 metropolitan districts covering the crowded populated urban areas [2. P. 3].

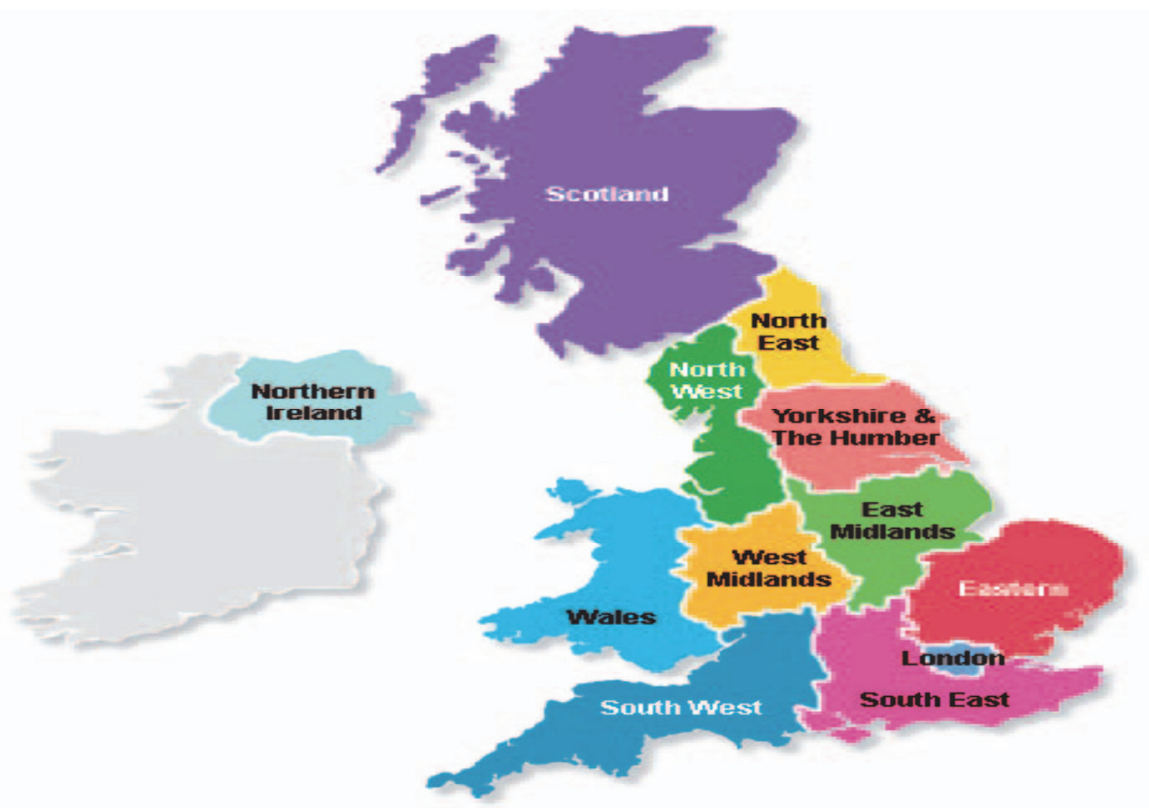

Fig. 1. The nine regions in England and Wales,

Scotland and Northern Ireland

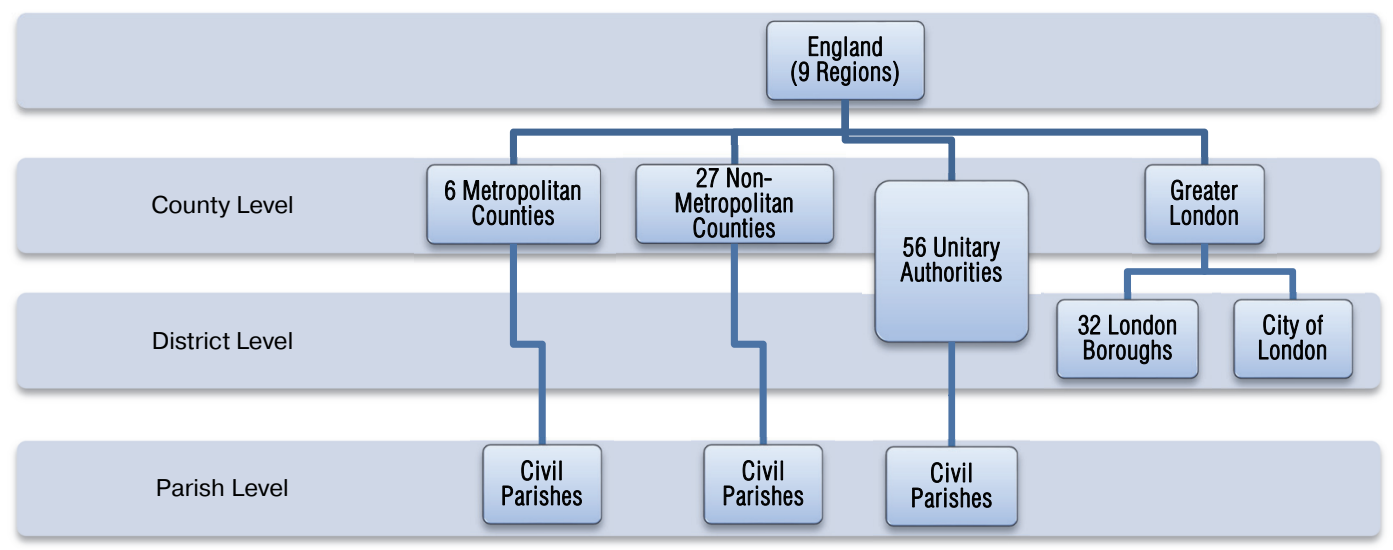

Fig. 2. Structure of local government in England

\section{B) London Boroughs (Greater London)}

The London boroughs are administered by London Borough Councils, which are elected every four years. The boroughs are the principal local authorities in London and are responsible for running most local services in their area, such as schools, social services, waste collection and roads. In 2001, the population of London had fallen to 7.2 million and was expected to rise towards 8 million by 2020 [7. P. 3]. 
In all, there are 32 boroughs in the City of London, each with their own local government, school centers, suburbs and proud sense of identity and history. Each borough has a representative in Parliament. The boroughs are divided into five groups: the Inner East and South, Inner West, Outer South, Outer West, North West, and Outer East and North East [12. P. 9].

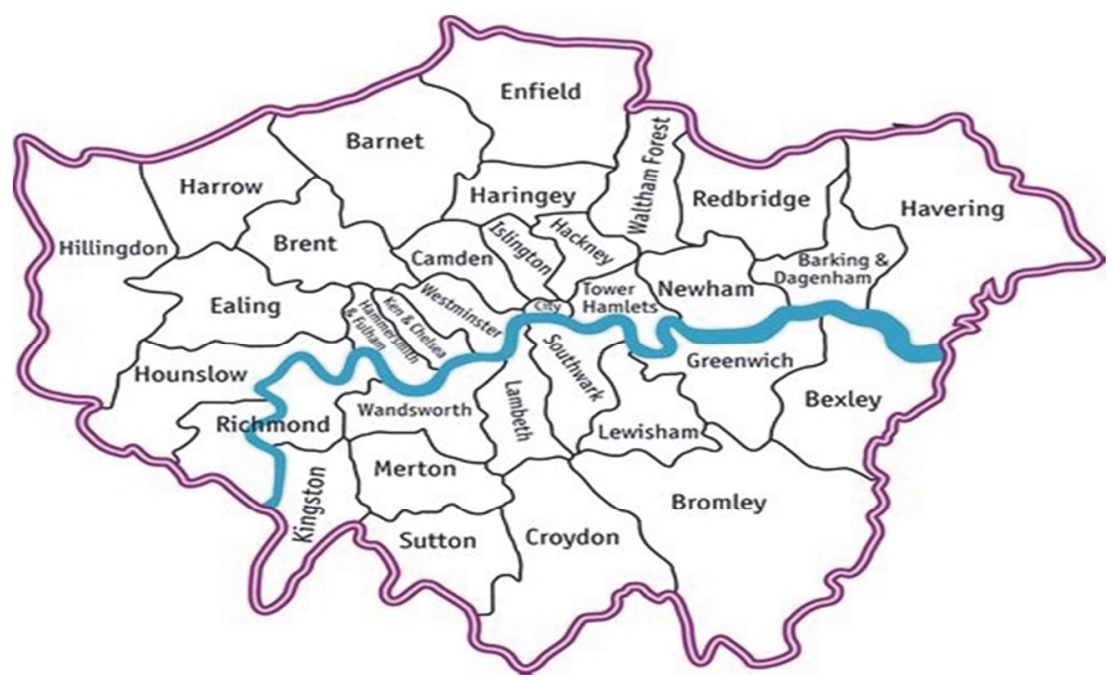

Fig. 3. Map of London Boroughs

\section{C) Unitary Authorities}

These local authorities are responsible for the provision of a variety of services within districts administrated by two different councils. As of the last amendment in 2009, there are 56 unitary authorities in England. "This single tier pattern, which had been put in place in metropolitan counties, was supposed to reduce bureaucracy and costs and provide for greater accountability" [1. P. 57].

Typically, unitary authorities cover towns or cities which are large enough to function independently of the county or other regional administration. Sometimes they consist of further sub-divisions which differ from the rest in that they provide a single authority and have no lower levels of administration.

\section{Two-Tier Authorities}

Two-tier authorities are essentially county and district councils working together to deliver services.

\section{D) County councils}

These authorities deliver all-encompassing services (core services), such as education, healthcare, utilities, etc. Each council covers a population in the range of 500000 1500000 .

\section{E) Districts}

Districts focus on smaller, more localized services, such as tourism, each covering a population of about 100 000. "District" can also be referred to as a "borough" or a "city council". 


\section{TOWN AND PARISH LEVEL}

In some areas there are parish and town councils, which are the lowest level of local government. Parish councils are responsible for bus shelters, burial grounds, allotments, Christmas lights, village halls and other smaller scale arrangements. There are over 8000 town and parish councils in England, mainly in rural and semi-rural areas [18. P. 73].

Sometimes a parish council may be referred to as a town. In Wales, a parish council is called a community council. Parish councils are not essentially planning authorities, but they can be consulted on certain local planning and development matters [19. P. 52].

The responsibilities of county and district councils in UK

\begin{tabular}{|c|c|c|}
\hline Activity & County Councils & District Councils \\
\hline County farms & All services & \\
\hline Education & All services & \\
\hline $\begin{array}{l}\text { Highways and } \\
\text { transportation }\end{array}$ & $\begin{array}{l}\text { Transportation planning } \\
\text { Constructing new county roads } \\
\text { Maintenance of county roads } \\
\text { Public transport } \\
\text { infrastructure and co-ordination } \\
\text { Highways and street lighting } \\
\text { Public right of way }\end{array}$ & $\begin{array}{l}\text { Street cleansing } \\
\text { Street lighting }\end{array}$ \\
\hline Housing & & All services \\
\hline $\begin{array}{l}\text { Leisure } \\
\text { and amenities }\end{array}$ & $\begin{array}{l}\text { Libraries } \\
\text { Archaeology } \\
\text { Archives } \\
\text { County Parks and picnic sites } \\
\text { Grants to village halls, sports, arts, coun- } \\
\text { tryside and community projects }\end{array}$ & $\begin{array}{l}\text { Allotments } \\
\text { Museums/art galleries } \\
\text { County parks, local parks \& open } \\
\text { spaces } \\
\text { Playing fields, other than schools } \\
\text { Swimming pools and sports centers }\end{array}$ \\
\hline Planning & $\begin{array}{l}\text { Structure plans } \\
\text { Minerals control } \\
\text { Environment and conservation } \\
\text { Economic and tourism development } \\
\text { Waste disposal control }\end{array}$ & $\begin{array}{l}\text { Local plans } \\
\text { Development control } \\
\text { Local land and charges } \\
\text { Environment and conservation } \\
\text { Economic development }\end{array}$ \\
\hline Public protection & $\begin{array}{l}\text { Waste regulation and disposal, waste } \\
\text { recycling centers } \\
\text { Trading standards. } \\
\text { Registration of births, deaths and marriages } \\
\text { Coroner's office } \\
\text { Courts } \\
\text { Fire and rescue }\end{array}$ & $\begin{array}{l}\text { Refuse collection } \\
\text { Food safety and hygiene } \\
\text { Markets } \\
\text { Control of pollution } \\
\text { Cemeteries/ crematoria }\end{array}$ \\
\hline Social services & All services & \\
\hline Council tax & & $\begin{array}{l}\text { Collection of own tax, plus precepts for } \\
\text { county and parishes }\end{array}$ \\
\hline
\end{tabular}

Table 1 shows the activities of county and district councils [6. P. 101].

"Local authorities can only do what the law allows; all councils' powers derive from Acts of Parliament. Indeed, local government itself exists only by courtesy of the Parliament, which frequently alters its powers and functions" [6. P. 101]. 


\section{THE RELATIONSHIP BETWEEN CENTRAL GOVERNMENT AND LOCAL GOVERNMENT}

Generally, the government can use its majority in the Parliament to legislate a law determining what local authorities can and cannot do, a power used with great frequency by central government [6. P. 138]. Therefore, the relationship between the central and local governments has been tense.

While the local government's needs often contradict the central government's intention to ensure that its policies are carried out throughout the land, it is also assumed that the local government must be a primary representative of local interests. With this background, the ineptitude of informal networks and the need to regulate the relationship is evident.

According to Rhodes, there is a weak center in the UK's government system due to the increased complexity of its structure with resultant fragmentation and disorder, as well as the government's inability to control the levers and realize its objectives. He notes that the state has become a "collection of inter organizational networks made up of government and societal actors, with no sovereign actor being able to steer or regulate [13]. Thus, the central government has lost control of policy networks, which have acquired self-organizing capacities and resist central direction [11. P. 23].

\section{POLICY NETWORKS IN ENGLAND}

In England, policy making and policy implementation at the local level has quite a complex nature. The web of inter-organizational relations has been the key discussion point in political science circles. Inter-governmental relations have been subject to a great deal of criticism, which has led to an increasing concern about the necessity to improve policy networks [5. P. 121-122].

Nowadays, one of the important topics in British literature on policy making is policy network analysis. There is an ongoing discussion among authors. Dowding, for instance, mentions that "policy network analysis has become the best paradigm for studying policy-making process in British political science" [3. P. 136]. Jordan adds that although the idea of "network" is now a commonplace term in policy-making studies, there is lack of substance to the term [10. P. 319-320]. Hay, however, claims that the "network paradigm" is "reshaping the political, economic, and social landscape of the advanced industrial societies" [8. P. 33].

In the late 1970s, Richardson and Jordan proposed the term 'policy community' to refer to organizational subsystems, and later, Marsh and Rhodes attempted to systematise and clarify these terms in order to develop the idea of networks [14].

Rhodes talks about five dimensions of networks: 1) group of interests (interests vary according to services or client groups); 2) members (public or private groups); 3) vertical independence (the degree of independence of a policy network from the actors); 4) horizontal independence (the interconnections between upper and lower levels); 5) distribution of resources (allocation of resources that need to be exchanged) [13. P. 77].

Policy networks are defined as a means of categorizing the relationship between organizational groups and the government. Smith and Rhodes describe a policy network as a "cluster or complex of organizations connected to each other by resource depend- 
encies and distinguished from other clusters or complexes by breaks in the structure of resource dependencies" [15. P. 7; 14. P. 14].

Rhodes' model is completely different from the one offered by Richardson and Jordan (1979) in the way it determines different types of networks. Richardson and Jordan use the term "policy community" to describe all types of relations between the state and organizational groups, while Rhodes distinguishes between relations in different areas of policy on the basis of composition, integration, and interdependence. The Rhodes Model is presented as a meso-level concept, addressing the structural relationship between units of sub-central government, as opposed to a micro-level concept looking at relationships within specific units of the government.

Rhodes assumes that policy is made and implemented by a group of organizations, which include government branches. These organizations are interdependent and act in accordance with one another in order to meet their goals. Most importantly, groups of organizations quite naturally develop straightforward connections among themselves because of their shared interests [9. P. 153].

Policy networks take place when there is an exchange of information and resources between different groups of organizations and central government. The exchange of information can be minimal, in the case of a group submitting a proposal in writing, or complex, with groups that have institutional access to government and are involved in the detailed development of policy [15. P. 56].

Table 2

R. Rhodes [14. P. 14] classified five distinct types of policy network

\begin{tabular}{|ll|l|}
\hline \multicolumn{2}{|c|}{ Type of Network } & \multicolumn{1}{c|}{ Characteristics } \\
\hline 1. & $\begin{array}{l}\text { Policy community } \\
\text { "territorial" }\end{array}$ & $\begin{array}{l}\text { Stability, highly restricted membership, limited vertical interdepend- } \\
\text { ence, limited horizontal articulation }\end{array}$ \\
\hline 2. & Professional network & $\begin{array}{l}\text { Stability, highly restricted membership, vertical interdependence, } \\
\text { limited horizontal articulation, serves interest of profession }\end{array}$ \\
\hline 3. Intergovernmental network & $\begin{array}{l}\text { Limited membership, limited vertical interdependence, serves } \\
\text { interest of producer }\end{array}$ \\
\hline 4. $\quad$ Producer network & $\begin{array}{l}\text { Fluctuating membership, limited vertical interdependence, serves } \\
\text { interest of producer }\end{array}$ \\
\hline 5. Issue network & $\begin{array}{l}\text { Unstable, large number of members, limited vertical interdepend- } \\
\text { ence }\end{array}$ \\
\hline
\end{tabular}

This variation between policy networks has important implications for the relationships that exist between different parts of the governmental system, and between government and the private sector. In addition, these inter-organizational relations have a major impact on how functions of subnational governmental authorities are actually managed and fulfilled [5. P. 123].

One flaw of this classification is that it takes into account only five types of networks. This number seems highly unlikely. For example, the authors' understanding of the intergovernmental networks is one-dimensional. The characteristics of such networks include topo-cratic membership (i.e. their authority is limited by the geographical area to which they belong), the services they provide, limited vertical interdependence and ability to penetrate a range of other networks [14. P. 13]. The authors do not cover the links between intergovernmental agencies or organizations, failing to analyze the context in which policy networks operate. In later works, Rhodes and Marsh 
focus on the disadvantages of this typology and make attempts to contextualize networks, representing them as a continuum [14. P. 183].

The authors describe the policy community and issue networks as located at the opposite ends of the continuum; however, the position of other types of networks on the continuum is not clear. Rhodes' model appears to merge two separate dimensions, with policy networks differing according to their integration and dominating interests [14. P. 184].

J.A. Chandler [2] argues that local authorities act as stewards of the central government, who are left to discharge their responsibilities, with the central government intervening only if the steward's conduct is found to have been unsatisfactory. The broad outlines of policy are determined nationally; local authorities play a substantial part in interpreting those policies and mobilizing the resources needed to bring them to fruition.

The debate about the relations between central and local governments has been centered around two models of policy networks: the agency model and the partnership model. The supporters of the agency model argue that the local authorities are the agents of the central government, responsible for carrying out the instructions of ministers and the Parliament. According to the partnership model, the role of local authorities is that of partnership with the central government in providing services for the public [4. P. 4-7].

\section{The Agency Model}

This model suggests that the local authorities have a subordinate relationship to the central government with little or no discretion in the task of implementing national policies.

In this model, however, while the central government departments put pressure on local authorities, the latter still retain some policy discretion in representation of central / local relationships. The model sees local authorities as something far more complicated than simple, uncritical, unthinking agents of the center [6. P. 140].

\section{The Partnership Model}

The Partnership Model sees authorities as more or less co-equal partners with central government in providing services.

Today, partnerships address a broader range of issues, such as the quality of life, and they are set up within networks that cover all parts of the country. Many of these networks have been created by the national government [6. P. 140].

\section{CONCLUSION}

A crucial distinction must be made between federalism and decentralization. Federalism, for example, in the USA, grants subunits of government a final say in certain areas of governance; it grants these governments definitive rights against the center. Decentralization in UK, in contrast, is a managerial strategy by which a centralized regime can achieve the results it desires in a more effective manner.

The effectiveness of any decision making unit depends on a variety of factors, including the available information, the quality of personnel, the level of control over subordinates, and perceived prestige among those who must follow commands. 
These factors suggest that sometimes the most effective decisions will be made by the central government and that sometimes they will be made by a geographical subdivision.

A central government can achieve uniformity and may be able to command greater resources and prestige.

A subsidiary government may be able to gather information more effectively, to control street-level employees, and to respond to circumstances, that are specific to its locality.

The choice between those two alternative strategies - that is, the particular allocation of responsibility within the overall structure - is determined by the effectiveness of each strategy in achieving the desired result. In decentralization, as opposed to federalism, the central government identifies this result and thus defines the criteria for success or failure, and the central government decides how decision making authority will be divided between itself and geographical subunits.

If we compare the systems in Britain and the United States, we will find the following differences: Britain is a unitary state, and thus we can observe that the sovereignty exists at the center, in the Parliament, even if power may be delegated to other local units. By contrast, the United States is a federal country in which sovereignty is divided between the center (Washington) and the regions, the division of responsibility being set out in the constitution.

Britain, for example, has been exhibiting a high degree of central control for a long time; nowadays, there has been a move towards a degree of decentralization.

Finally, the United States is less centralized than Britain; the allocation of power between Washington and the states is more straightforward than the power distribution that exists between London and the UK national capitals.

\section{REFERENCES}

[1] Barry C., Vincent N. Town and Country Planning in the UK. $13^{\text {th }}$ edition. UK: Routledge; 2003. $602 \mathrm{p}$.

[2] Chandler J.A. Local Government Today. 3rd edition. UK: Manchester Press; 2001. 303 p.

[3] Dowding K. Model or Metaphor? A Critical Review of the Policy Network Approach. Political Studies. 1995; 43: 136-158.

[4] Elcock H. Local Government; Policy and Management in Local Authorities. UK: Routledge; 1994. $353 \mathrm{p}$.

[5] Gray C. Government beyond the Center: Sub National Politics in Britain. UK: Macmillan press; 1994. $212 \mathrm{p}$.

[6] Greenwood J., Pyper R., Wison D. New Public Administration in Britain. Third Edition. UK: Routledge; 2002. 304 p.

[7] Hamnet Ch. Unequal City: London in the Global Arena. UK: Routledge; 2003. 292 p.

[8] Hay C. The Tangled Webs We Weave: the Discourse, Strategy and Practice of Networking. Marsh D. Comparing Policy Networks. Buckingham: Open University Press; 1998: 33—51.

[9] Hudson J., Lowe S. Understanding the Policy Process; Analyzing Welfare Policy and Practice. 2nd edition. UK: Policy Press, University of Bristol; 2004. 352 p.

[10] Jordan A.G. Sub-Governments, Policy Communities and Networks Refilling the Old Bottles. Journal of Theoretical Politics. 1990; 2 (3): 319-338.

[11] Laffin M. Central Local Relations in an Era of Governance: Towards a New Research Agenda. Local Government Studies. 2009; Vol. 35; 1: 21-37. 
[12] Maclnnes T., Kenway P. London's Poverty Profile. UK: New Policy Institute; 2009. 100 p.

[13] Rhodes R.A. Beyond Westminster and Whitewall. UK: Unwin Hayman; 1988. 480 p.

[14] Rhodes R.A., Marsh D. Networks in British Government: Policy Communities and Issue Networks: Beyond Typology. UK: Clarendon Press; 1992. 295 p.

[15] Smith M.J. Pressure Power and Policy: State Autonomy and Policy Networks in Britain and United States. UK: Harvester Wheatsheaf; 1993. 262 p.

[16] The Local State We're In. PwC's Annual Local Government Survey 2018. PwC. Available from: https://www.pwc.co.uk/industries/government-public-sector/local-government/insights/ local-state-we-are-in-2018.html. Accessed: 06.09.2018.

[17] Throp C. Countries around the World: England. UK: Raintree Publisher; 2012. 48 p.

[18] Turner T.J. Local Government: Disclosure and Comparisons. USA: University Press of America; 2005. $204 \mathrm{p}$.

[19] Denyer-Green B., Ubhi N. Development and Planning Law. $4^{\text {th }}$ edition. UK: Elsevir Ltd; $2010.418 \mathrm{p}$.

DOI: 10.22363/2313-1438-2018-20-4-516-524

\title{
МЕСТНОЕ САМОУПРАВЛЕНИЕ И ПОЛИТИЧЕСКИЕ СЕТИ В ВЕЛИКОБРИТАНИИ: АНАЛИТИЧЕСКОЕ ИССЛЕДОВАНИЕ
}

\author{
М. Халифа \\ Университет прикладных наук \\ 315 Шахаб Роад, Манама, Бахрейн \\ Университет Суэцкого канала \\ 4.5 км. Ринг Роад, Исмаилия, Египет, 41522
}

В Великобритании под местными органами власти понимаются органы власти и зависимые учреждения, которые создаются в соответствии с законодательством под руководством избираемого на местном уровне совета для предоставления услуг в отдельных населенных пунктах и представления своих интересов. Так как Великобритания не является федеративным государством, там нет разделения полномочий между центральным правительством и органами местного самоуправления. Вместо этого центральное правительство обладает всеми государственными полномочиями и осуществляет государственную политику. В представленной статье исследуются отношения между центральным правительством и местными органами власти в стране, а также уточняются институциональные механизмы отношения между ними. Автор анализирует современные модели политических сетей в Великобритании и выявляет их отличия от федеративных систем.

Ключевые слова: местное самоуправление, политические сети, органы местного самоуправления, государственная политика

\section{Сведения об авторе:}

Махмуд Калифа - PhD, старший преподаватель Университета прикладных наук (Бахрейн) и Университета Суэцкого канала (Египет), приглашенный научный сотрудник Университета Линкольна (Великобритания) (ORCID ID: 0000-0003-2673-5366) (e-mail: m.khalifa@commerce.suez.edu.eg).

\section{Information about the authors:}

Mahmoud Khalifa - PhD, Senior Lecturer of Applied Science University (Bahrain) \& Suez Canal University (Egypt), Visiting Fellow of the University of Lincoln (UK) (ORCID ID: 0000-0003-2673-5366) (e-mail: m.khalifa@commerce.suez.edu.eg).

Статья поступила в редакцию 07.09.2018.

Received 07.09.2018. 